\title{
EN TORNO A LA OBRA TEÓRICO-LITERARIA Y FILOLÓGICA DE MENÉNDEZ PIDAL Y EL «CENTRO DE ESTUDIOS HISTÓRICOS»
}

FRANCISCO ABAD

UNED. Madrid

fabad@flog.uned.es

\section{RESUMEN}

Este artículo sistematiza los principales conceptos teórico-literarios de Menéndez Pidal y sus discípulos directos.

Palabras Clave: «Centro de Estudios Históricos», Menéndez Pidal, Dámaso Alonso, Amado Alonso.

\section{RÉSUMÉ}

Cet article systématise les principaux concepts théoriques et littéraires de Menéndez Pidal et de ses disciples les plus proches.

Mots-Clef: «Centro de Estudios Históricos», Menéndez Pidal, Dámaso Alonso, Amado Alonso.

\section{INTRODUCCIÓN}

La llamada a veces «escuela de Madrid» es la que se formó en torno al maestro don Ramón Menéndez Pidal en el seno del «Centro de Estudios Históricos» de la «Junta para 
Ampliación de Estudios» entre 1910 y 1936, año en que su trayectoria quedó interrumpida por la guerra civil y luego por la decisión de los vencedores de la misma, que fueron siempre muy adversos a todo lo pidalino; en realidad huellas de ese rechazo primero político y luego más bien social hacia los miembros de la escuela, llegan hasta nuestros mismos días: deseamos ilustrarlo algún día.

Con el esfuerzo personal de don Ramón se fundamentan entre nosotros algunos capítulos de la filología científica, la hoy todavía vigente, de tal manera que hay un antes y un después muy notorio en la filología española en relación a nuestro autor; él fue muy escrupulosamente positivista - en el sentido metodológico, no en el conceptual, y desde luego en la mejor acepción de la palabra-, muy analítico y riguroso. Su nieto y asimismo filólogo de relieve (y que ya no vive tampoco) Diego Catalán, ha percibido con acierto que «para conquistar la exactitud filológica y contener la arbitrariedad subjetiva, Menéndez Pidal rechazó decididamente la imagen del escritor «polígrafo» dominante en los ambientes nacionales, y limitó austeramente su campo de actividad. Esta limitación tiene su complemento en el aspecto formal: Menéndez Pidal arrinconó el estilo oratorio de la época haciendo gala de una extrema sobriedad expositiva» (Catalán, D., 1974: 25).

Menéndez Pidal venía haciendo su obra personal desde finales del Ochocientos, pero con la creación de la «Junta» en 1907, y específicamente del «Centro» en 1910, encontró un lugar institucional en el que efectivamente seguir con la obra propia y crear además escuela, la escuela — como tal — de mayor relieve en toda la historia de los estudios filológicos en España.

Don Ramón llegaba a la jubilación de su cátedra en 1939, por lo que el tiempo de mayor plenitud de su trabajo - trabajo en todo caso siempre inigualadamente logradocoincide con el del «Centro de Estudios Históricos»; en el mismo estuvo el maestro de los cuarenta a los sesenta y cinco años de su edad, y allí logró su obra personal (aunque también la lograría antes y después), y asimismo impulsó con decisión la de sus discípulos y la de los discípulos de sus discípulos.

Cabe sistematizar desde luego algunos de los conceptos teórico-doctrinales de Menéndez Pidal en torno a la literatura, aunque no nos detendremos sólo en las fechas del «entro».

\section{MENÉNDEZ PIDAL}

La pertenencia pidalina al noventayocho fue subrayada hace ya bastantes años por Dámaso Alonso, por Diego Catalán y José Luis Abellán, etc. Sin embargo no cabe olvidar que en don Ramón actuó en confluencia en parte con el noventayocho - generación de verdaderos clásicos en las letras españolas - otra tradición de gran impronta: la del krausismo español. La impregnación krausista de nuestra literatura de la segunda mitad del siglo XIX y del primer tercio del siglo XX es un hecho cierto - Ángel del Río lo advirtió alguna vez- , y en ese marco hay que situar asimismo a Menéndez Pidal: su austeridad personal de vida y el esfuerzo mantenido en ella, la independencia de conciencia y un tono laicista, el gusto por las tradiciones y lo folclórico, la demofilia, etc., le inscriben en tal serie del krausismo español, como asimismo creemos que a ella respondieron en parte Galdós o García Lorca; de hecho la Junta para Ampliación de Estudios y el 
Centro de Estudios Históricos en los que tanto papel tuvo don Ramón, eran instituciones llenas de ese espíritu krausista.

Nosotros formularíamos cómo Ramón Menéndez Pidal era persona de implantación krausista pero que por su edad pertenecía a los hombres del 98, y ese noventayochismo incidió en su krausismo. El gusto por el excursionismo, por las tradiciones españolas, por el folclore, por el arte tradicional, por la intrahistoria toda, caracterizan entre nosotros a Giner de los Ríos y a sus gentes, y tal herencia la hace suya de manera muy decidida don Ramón; la mejor España intelectual contemporánea creemos nosotros que es justamente la que lleva en sí la impronta institucionista y gineriana.

Hay un libro precioso de Manuel Bartolomé Cossío (De su jornada) que cualquier profesor español creemos que debiera leer, y en el que se estampa por ej. a propósito de la enseñanza de la historia en la Institución Libre de Enseñanza, que la misma «tiene desde el comienzo carácter de Historia de la cultura» y que en ella «se habla más de los pueblos que de los personajes [...] despertando la idea (sin decirlo) de que todo lo que hay se hace por todos, y de que el verdadero sujeto de la historia no es el héroe sino el pueblo entero, cuyo trabajo de conjunto produce la civilización» (Bartolomé Cossío, M., 1929: 26-27). Menéndez Pidal hizo suya ciertamente una historiografía romántica, y ese romanticismo le llevó a ponderar la acción de los héroes (el Cid, los conquistadores de América con sus «ilustres hazañas», etc.), pero asimismo operó en él la otra impronta de la mentalidad krausista, y de ahí su populismo — en el sentido más noble de la voz-.

Don Ramón no estudió por ej. sino por ineludible necesidad científica y en la medida en que hacía falta el llamado mester de clerecía; él se ocupó en cambio de los juglares y de la poesía juglaresca, que en definitiva era tradicional y en parte obra de todos, y trató también del lenguaje y del romancero, productos asimismo muy tradicionales; de hecho elaboró — según vamos a ver inmediatamente — una tipología de los hechos filológicos tradicionales.

Si leemos las obras del maestro encontramos en efecto en las mismas conceptos teórico-literarios, como por ej.,

1), el de «estado latente». «Los contemporáneos de tal hecho o uso social -manifiesta- no se dan cuenta de él porque viven apartados del medio en que se produce y lo desconocen, o conociéndolo no dan cuenta de él porque no lo creen digno de atención; por cualquiera de estas causas de latencia coetánea se produce la latencia entre los observadores posteriores que se ven privados de datos respecto al hecho en cuestión» (Menéndez Pidal, R., 1957a: 340).

Se trata por tanto de una actividad colectiva o uso social que queda ocultado porque o se desconoce, o se halla relegado a grupos sociales incultos; sale de esa latencia cuando al hecho se vuelve a prestar atención por las gentes cultas o eruditas.

2) Don Ramón estableció también grados en la tradición, es decir, grados de consistencia tradicional en diversas actividades colectivas: lo más tradicional de todo le parecía el lenguaje - siempre en boca de todos y siempre empleado ininterrumpidamente- y de ahí que el individuo pueda intervenir difícilmente en cambiarlo; segundo grado de tradicionalidad (o sea, menor tradicionalidad) presenta el romancero (vid. Menéndez Pidal, R. 1957a: 367-368).

El romance posee menor grado de tradicionalidad que el lenguaje, en su vida intervienen menos gentes, se halla en boca de menos — la lengua la hablan todos—, y así una 
innovación feliz puede incorporarse al texto romanceril, resultar aceptada, y emigrar a varios lugares y difundirse.

Por fin el que don Ramón llama tercer grado de tradicionalidad (que hay que entender como de tradicionalidad menor) es el del cantar de gesta: ahora «al ser menor el número de cantores y de oyentes que intervienen en la trasmisión, las variantes orales pueden introducirse más libremente», y de esta manera —en general— el juglar puede rehacer y refundir los relatos épicos.

3) Frente al concepto de poesía popular que agrada a todos en general, don Ramón estableció el de «poesía tradicional», la poesía que cuando se repite no se repite fielmente sino que se rehace en más o en menos: esta poesía «que se rehace en cada repetición, que se refunde en cada una de sus variantes, las cuales viven y se propagan en ondas de carácter colectivo a través de un grupo humano y sobre un territorio determinado, es la poesía propiamente tradicional». La poesía tradicional se reelabora por tanto por medio de las variantes (Menéndez Pidal, R., 1973: 325-356).

En realidad del lenguaje — cabe añadir - puede decirse que vive asimismo en variantes, es decir, en continua diferenciación o dialectalidad interior; incluso otros textos de las letras castellanas han vivido en algún sentido en variantes, por ej. el teatro del XVII, que se transmitía mediante la memoria o en textos manuscritos que inevitablemente conllevaban verdaderas variantes (Menéndez Pidal, R., 1971: 73-74; 77; 81).

4) Nuestro autor distinguió asimismo — al tratar de la poesía tradicional— entre las épocas «aédica» y «rapsódica» del romancero: «De una parte —escribía- hay que considerar una actividad aédica, creadora; los poetas [...] se aplican a producir composiciones en estilo cantable popular, es decir, destinadas a un público mayoritario [...]; de otra parte, una actividad rapsódica limitada a repetir lo antes poetizado, eliminando en ello todas las formas de expresión no asimilables por el común de los recitadores, interviniendo en corta medida cada recitador con retoques improvisados. Las dos actividades se mezclan siempre, pero la época de orígenes y florecimiento es predominantemente aédica, y a ella sigue la época predominantemente rapsódica». En concreto y por lo que respecta al romancero hispánico, ocurre que su época aédica dura con gran actividad productora hasta muy avanzado el Quinientos (Menéndez Pidal, R., 1968, II, 16-19).

5) Menéndez Pidal interpretó como un rasgo de poética —una «gala poética», decía- el de la conservación del uso de la llamada — e paragógica (esto es, las rimas cibdade, mare, asonando con padre, etc.); en realidad tal $-e$ interpretaba que no es paragógica (paragoge: «figura de dicción que consiste en la adición de algún sonido al fin de un vocablo»): «es etimológica, y data de una época en que la — $e$ final latina se conservaba aún»; nos hallamos así ante un hecho originariamente etimológico y conservado luego por tradición a manera de ornato poético.

Estas rimas con la —e «eran muy usadas en la lengua común —aclara don Ramónen la primera parte del siglo XI, y sólo fue posible que se siguieran usando en los cantares de gesta de los siglos XII y sucesivos gracias al poderoso ascendiente que pudieron ejercer los relatos épicos de los siglos X y XI sobre los refundidores y poetas épicos posteriores» (Menéndez Pidal, R., 1970, 88-90).

6) Menéndez Pidal analizó asimismo la reiteración estilística presente en el romancero, y esta «repetición» la conceptúa en tanto figura caracterizadora del mismo: «La principal figura retórica usada en el estilo tradicional es la repetición. El lirismo gusta re- 
mansarse reiterando sus efusiones. Esta reiteración [...] es sin duda lo que más distingue el estilo épico-lírico de los romances respecto al estilo propiamente épico de las gestas» (1968, I, 78-80).

7) Nuestro autor delimita conceptualmente asimismo lo que es el idioma escrito: «"El habla escrita" es un acto perdurable que se dirige no a un oyente inmediato, sino a un lector por lo general desconocido, actual o futuro. El paso de la forma oral a la escrita provoca en el sujeto, cualquiera que sea su condición social, un afán de superación, un esfuerzo deliberado por incorporarse al ambiente cultural común. Fundamentalmente exige un trabajo de estudio y corrección para eliminar del habla espontánea la rapidez o la lentitud ocasionales del momento, y lograr la precisión que reclama la lectura, acto de atención más tensa, comparado a la audición, acto de percepción más pasiva. [... La lengua escrita] siempre se distingue de la hablada por el artificio y mayor compostura» (Menéndez Pidal, R., 2005, II, 19-21). Nos encontramos en efecto ante un artificio.

8) En fin don Ramón tiene un concepto de la lengua literaria que supone al menos dos diferentes acepciones de la idea, y que expone de esta manera (Menéndez Pidal, R., 2005, II, 19-24): «Como acto artístico perdurable, tendiendo a una expresión que sirva para todos y para todo, [la lengua literaria] prefiere las formas lingüísticas de mayor ámbito de comprensibilidad, las de mayor arraigo en el idioma, las más nobles, las que menos han rodado en el habla vulgar y menos se han contaminado en los empleos bajos de la vida, las que se hallan consagradas en las más hermosas realizaciones que la lengua ha tenido bajo la pluma de los escritores antepasados. [...] La lengua literaria puede ir informada por un propósito principalmente estético o por uno utilitario, y será poética o prosaica. Por sus caracteres rítmicos puede ser versificada o prosística, y claro es que una obra versificada puede ser prosaica y una obra prosística puede ser poética. El habla poética por su liricidad, por su vibración emocional, realiza el mayor esfuerzo de invención o subjetividad creadora». Hay una idea de lengua literaria que la identifica en la práctica con la lengua poética, y así parece hacerlo a veces nuestro autor, quien en otras ocasiones entiende en sentido más amplio que la lengua literaria es simplemente la no vulgar, y que ella comprehende la lengua propiamente poética, que a su vez se manifiesta bien en verso bien en prosa (para todo lo anterior, vid. más detalles en Abad, F., 2008, 165-174).

\section{EL «CENIT» DE LA LITERATURA ESPAÑOLA}

Menéndez Pidal estimaba que la cima de las letras castellanas ocurrió a fines del siglo XVI y en los comienzos (primeras décadas) del XVII; por ej. en la Antología de prosistas españoles decía que «el último tercio del siglo XVI (incluyendo los primeros decenios del XVII) señala el punto más alto de gloria a que llegó nunca la prosa castellana, tanto en hermosura como en difusión por todo el mundo civilizado». En realidad - y según había notado años antes - la lengua castellana comprendió en sí desde fines de la centuria del Cuatrocientos «los productos literarios de toda España (pues en ella colaboraron hasta los más grandes autores portugueses, como Gil Vicente [...])».

A partir del reinado de Fernando e Isabel (cfr. Menéndez Pidal, R., 1950, para varias de las ideas que siguen) se acumularon hechos decisivos en el hablar común y en el lenguaje literario: unificación de los dos grandes dialectos afines, castellano y aragonés; apa- 
rición de la imprenta en la Península (organismo de uniformación tipográfica y en definitiva lingüística); descubrimientos geográficos; dispersión de los judíos españoles; empresas de Italia; ...; todos ellos fueron sucesos «llamados a modificar [...] la vida del idioma». En efecto el idioma castellano se hace ahora lengua española por su mayor vigencia y por resultar vehículo de una literatura muy caudalosa. Asimismo al comienzo del reinado de los Reyes Católicos la obra maestra de Jorge Manrique — las Coplas - quebró «la dirección estilística predominante en la alta literatura»: se dio pues una nueva manera de lenguaje artístico-literario.

El llamado «español clásico» estima así don Ramón que comienza a manifestarse con las ya aludidas Coplas manriqueñas y con La Celestina. La creación de Jorge Manrique supone «una avanzada del siglo siguiente en que Valdés formulará la gran norma de la selección antes que la innovación»; en cuanto a Fernando de Rojas, La Celestina resulta «obra de transición a la sencillez», y no desprendida todavía del todo del retoricismo cuatrocentista. Los autores literarios clásicos, los «clásicos castellanos», vemos cómo se postula que se inician con Manrique, estimación que luego han seguido otros autores (Fernando Lázaro, etc.).

Asimismo es del tiempo de los Reyes Católicos el Cancionero General de 1511, y en el mismo hallamos «un primer conceptismo»: «los poetas contemporáneos de los Reyes Católicos coleccionados por el gran Cancionero, reaccionan mediante ese conceptismo contra el retoricismo de antes». La serie literaria se le aparece así a Menéndez Pidal en tanto un oponerse o «escribir contra»: al retoricismo se opone una manera de conceptismo.

Entrando ya en el Quinientos de la lengua, delimita Menéndez Pidal (cfr. su 1968) un «período de Garcilaso» y otro «período de los grandes místicos» en nuestra historia idiomática. En el primero de estos momentos y según es sabido «se imponen en la poesía española los metros de Italia, y con ellos entran los temas, las expresiones y los giros de la poesía de allá, acompañados de multitud de vocablos italianos». Destaca don Ramón el sabor de modernidad que tendrá ya para todas las épocas posteriores la poesía garcilasiana, «debido a la atinada elección de lo más usual, de lo más popular, de lo más natural, que al fin y al cabo es lo más permanente del idioma, lo más sustraído a los influjos efímeros de la moda» (Menéndez Pelayo había advertido a su vez la modernidad de la prosa desde los años iniciales del reinado de Carlos V); interpreta por otra parte Pidal el estilo literario de fray Antonio de Guevara, y dice entonces: «los sustantivos, los adverbios, los verbos se repiten en parejas sinónimas: las parejas de vocablos se acompañan de parejas de frases, ora reiterantes, ora antitéticas, y de cuando en cuando se hacen resaltar estos paralelismos con una llamativa similicadencia, todo ello para ablandar la atención, empapándola de la idea».

A su vez el llamado «período de los grandes místicos» es aquel en que la lengua hablada (analizaba nuestro autor) adquiere los caracteres fonéticos que hoy mismo la distinguen; en términos más amplios Rafael Lapesa por ej. ha entendido que el cambio en el consonantismo que determinó el paso del fonetismo medieval al moderno tuvo su generalización entre la segunda mitad del siglo XVI y la primera del XVII, y así lo dijo ya en la primera edición (1942) de su Historia de la lengua, pero el maestro gallego-asturiano insistió particularmente en la trascendencia de este tercio de siglo (1555-1585) en el cual además se nos ofrece «un extraordinario culminar de la literatura religiosa». En cuanto al hablar común tenemos pues que dado el cambio generalizado en la pronunciación y otras 
circunstancias como la capitalidad de Madrid, etc., la lengua normativa ya no es «sino el habla de la nación entera» y no la de Toledo que había tenido vigencia en las centurias bajomedievales (de Alfonso X a Juan de Valdés, según simbolizó una vez el propio don Ramón).

Menéndez Pidal advierte que nos encontramos ahora —entre 1555 y 1585 — con el momento de convivencia de nuestros cuatro más grandes escritores místico-ascéticos, que fueron los dos Luises, Santa Teresa y San Juan de la Cruz. Fray Luis de Granada fue «el primer escritor que hizo sentir toda la fuerza oratoria de que era capaz la lengua vulgar. [...] Fue el primero que trabajó esforzadamente por dotar a la lengua escrita de un período amplio, de rotundez oratoria y silogística, para superar las cláusulas cortas y sencillas de la conversación familiar» (Menéndez Pidal, R., 1963, para varias observaciones que siguen); además defiende el uso del idioma vulgar en el momento crítico de la Contrarreforma.

En cuanto a Teresa la Santa, don Ramón interpreta que sus formas popularizantes «pertenecen sin duda al habla grosera y ermitaña que [ella] adopta por humildad». Teresa sin embargo se ve llevada a contrariar la habitual llaneza del idioma cuando intenta la expresión de lo inefable, y entonces los vocablos antitéticos se agolpan en la expresión ( $\mathrm{glo}$ rioso desatino, celestial locura, etc.). En conjunto Santa Teresa - al decir pidalino«propiamente no escribe, habla por escrito; el hervor de la sintaxis afectiva rebasa a cada momento los cauces gramaticales ordinarios».

Fray Luis de León — reseña a su vez Menéndez Pidal— es escritor de empeño consciente dirigido al perfeccionamiento de la lengua artística: busca en todo caso «una sencillez muy esmerada». Así por ej. «prefiere en las cláusulas finales la terminación llana a la aguda», y de esta manera «corrigió atentamente casi en su totalidad Los nombres de Cristo y La perfecta casada de su primera edición [...] para publicar la 3. [...], y alteró muchas veces el orden de las palabras al parecer para lograr mejor ritmo». «El buen orden y concierto del lenguaje es tan natural en la mente reconcentrada y serena de fray Luis - concluye don Ramón - como lo es la irregularidad emotiva en el arrebatado espíritu de Santa Teresa».

En San Juan de la Cruz la lengua poética — de acuerdo con la observación de nuestro autor - comienza a desviarse en formaciones morfológicas y fraseológicas nuevas, y de esta manera «la norma de la naturalidad y perfecta comprensibilidad imperante en este siglo, empieza a sufrir contradicción»; en Fernando de Herrera por su parte asistimos a que «el odio a lo vulgar se extrema incluyendo en ello el habla común».

Herrera en efecto sabido es que postuló el logro mediante el entendimiento, de «modos nuevos i llenos de hermosura», aunque respetando la claridad que nace de las palabras: sin embargo «la oscuridad que procede de las cosas i de la doctrina, es alabada». Por esto - mantenía en su interpretación Menéndez Pidal— la poesía no es un arte para todos en la concepción herreriana; quiere ser un arte para los doctos.

Una época que va de 1585 a 1617 es la que Menéndez Pidal tiene por «período de Cervantes y Lope de Vega»: en el mismo no obstante ya «la lengua del Quijote no fué la característica». Luego de 1610 a 1713 irá la «época barroca»; al anterior período 15851617 lo caracteriza nuestro autor como de «culminación de la época clásica».

Las páginas en que don Ramón desarrolla su análisis del idioma castellano en el Barroco encierran agudas percepciones, por lo que resultan imprescindibles y en buena me- 
dida (por su densidad) refractarias al resumen (cfr. Menéndez Pidal, R, 1991, para lo siguiente). En una caracterización general del período de Cervantes y Lope de Vega escribe Pidal cómo «en los últimos años del siglo XVI y primeros del XVII el estilo de naturalidad corona la cumbre de su desarrollo, si bien en medio de vacilaciones que los dos más grandes escritores experimentaron en época diferente de su carrera: Cervantes al comienzo y Lope de Vega más tarde».

A su vez a inicios del XVII lo que ocurre es que «el espíritu de afectación literaria se despl[iega] en reacción victoriosa contra la agotada naturalidad de la época clásica [...] en todo Occidente»; vemos otra vez en la serie literaria la oposición a un sistema artístico anterior, una nueva manifestación del «escribir contra». Para las letras castellanas viene ahora el momento de mayor esplandor que nunca han tenido, su cenit: «El apogeo de la dilatada época barroca ocurre en sus comienzos, a raíz de los primeros éxitos de las escuelas culterana y conceptista. Podemos considerarlo limitado a un período de treinta años, hasta la muerte de Lope de Vega, en el cual conviven los más grandes cultivadores del idioma. Los que comenzaron en la época anterior dan a las tendencias de antes la más perfecta realización, o inician las nuevas corrientes; mientras los autores jóvenes producen todos sus frutos o los mejores. Es el cenit de la literatura española». Analiza Menéndez Pidal con detención (en La lengua castellana en el siglo XVII que estamos viendo) la llamada «segunda época» gongorina, aunque con objetividad hay que decir que se ha olvidado de tratar del primer Góngora, autor de composiciones logradas y atractivas también. Por igual se detiene don Ramón en trazar la secuencia de la polémica culterana, de la guerra literaria desatada a raíz de los grandes poemas de don Luis (el Polifemo y las Soledades).

Y frente al gongorismo, el conceptismo — estima — supone «un diverso estilo de artificiosidad», de tal manera que Quevedo busca la novedad en las creaciones idiomáticas «en las entrañas mismas del habla tradicional, no pidiéndola prestada al latín».

Nuestro autor estimaba en fin cómo hacia 1635/1637 se cerró «el período de más hervor de tendencias, de mayor actividad y brillo en la producción literaria española. Entonces aparecen las primeras obras de Gracián, que dan comienzo a otro período», de carácter más uniforme y — digamos por nuestra cuenta— a veces más repetitivo y estereotipado.

Sólo con las obras de Gracián (percibe por último don Ramón) el siglo de artificiosidad adquiere conciencia plena de sus ideales y propósitos, de su estética; no obstante —no se olvide que estamos ante páginas póstumas e inacabadas- al tratar del jesuita no lo hace de El Criticón.

Los estudios pidalinos sobre los estilos literarios han sido evaluados por D. Catalán, quien percibe cómo los análisis acerca del estilo de un autor no iban dirigidos en este caso a descubrir «el alma del artista, ni a recrear el acto de la creación poética, ni tampoco pretendían sensibilizar al lector respecto a una estética de otros tiempos. Su propósito era perseguir la transformación de los gustos colectivos, de la norma que gobierna el desarrollo de la lengua escrita, con precisiones cronológicas mayores que la tradicional división de la historia por siglos» (Catalán, D., 1974: 105).

Así ocurrió en verdad: el maestro buscaba trazar una cronología de períodos cortos identificables con la trayectoria del lenguaje literario castellano, con atención a la vez a los grandes cambios en el idioma común: cambio de la pronunciación consonántica — se- 
gún queda visto- hacia la época de los grandes místicos (1554-1585), etc. Hoy las Historias de la lengua parecen no considerar como asunto propio el de la historia de los estilos, lo que en nuestra concepción hace que pierdan contenido empírico notorio y desdibujen inevitablemente la cronología del idioma (sobre Menéndez Pidal y la historia lingüístico-literaria española, vid. Abad, F., 2008: passim).

\section{EL «CENTRO DE Estudios HistóRICOS»}

La «Junta para Ampliación de Estudios» hemos dicho que fue creada en 1907, y el «Centro de Estudios Históricos» surgió en su seno en marzo de 1910; la Memoria de la JAE de 1910-1911 habla de una «Sección» en ese «Centro» llamada de «Orígenes de la lengua española» y que estaba dirigida por D. Ramón Menéndez Pidal; años más adelante la Sección vamos a ver que cambiará de nombre. En estos primeros tiempos de Sección dedicada a los orígenes de la lengua española, la Memoria de los años sucesivos (documento imprescindible del que nos guiamos) registra diferentes investigadores que con una u otra cualidad se hallan vinculados a la misma: decimos que don Ramón figura como director, y también otros estudiosos que van apareciendo en tales Memorias son Tomás Navarro Tomás, Américo Castro, Federico Ruiz Morcuende, Justo Gómez Ocerín, Federico de Onís, Antonio García Solalinde, Florentino Castro Guisasola, Zacarías García Villada, Miguel Artigas o Eduardo García de Diego.

En el momento de la Memoria correspondiente á [...] 1914 y 1915 en efecto se habla ya de D. Ramón Menéndez Pidal en tanto «Presidente del Centro y Director de la Sección de Filología» del mismo; entonces figura Navarro como «Secretario del Centro». Desde entonces los nombres de investigadores que formaban parte de la sección filológica siguen aumentando, y aunque sea en algún caso creemos que por una sola vez, aparecen ciertamente registrados Benito Sánchez Alonso, Samuel Gili Gaya, Amado Alonso, Eduardo Martínez Torner, José F. Montesinos, Manuel Manrique de Lara, Vicente García de Diego, Emilio Alarcos García, Miguel Herrero García, Ernesto Giménez Caballero, Dámaso Alonso, Pedro Henríquez Ureña, Juan Dantín Cereceda, Pedro Sánchez Sevilla, José F. Pastor, Carmen Fontecha, Pedro U. González de la Calle, Agustín Millares Carlo, Rafael Lapesa, Homero Serís, Pedro Salinas, Lorenzo R. Castellano, Enriqueta Hors, Enrique Moreno Báez, Salvador Fernández Ramírez, etc.; adscrito a la sección creada en los tiempos finales del «Centro» de «Literatura contemporánea», aparece asimismo Vicente Llorens.

En una nómina tan amplia como la que constituyen las dos enumeraciones parciales anteriores debe haber colaboradores más o menos ocasionales, mientras otros constituyen el núcleo que se tiene por esencial de este «Centro de Estudios Históricos» de la «Junta...».

Existe por tanto una escuela pidalina de estudios literarios y de análisis del estilo; sus nombres quizá más característicos — pero no los únicos— son los del propio don Ramón (épica, historiografía, romancero, calas en los «siglos de oro»), más los de Tomás Navarro Tomás (métrica), Américo Castro (estudioso en estos años del Renacimiento y del Barroco), Federico de Onís, Homero Serís, Eduardo Torner, Amado y Dámaso Alonso, Solalinde, Pedro Salinas, Montesinos, Llorens, Lapesa, etc. Hay además —según decimos-otros investigadores vinculados por pocos o bastantes años al Centro de Es- 
tudios Históricos y que quedan reseñados, y existen —en la propia familia del maestrodos discípulos suyos directos que por edad no pudieron alcanzar esos años del «Centro»: se trata de Álvaro Galmés y de Diego Catalán.

El «Centro de Estudios Históricos» fue creado —según queda repetido- en 1910, luego de unos años difíciles para la supervivencia de la propia «Junta» durante el gobierno de Maura (tan sombrío en otros aspectos); será ahora y hasta la guerra civil, cuando se desarrolle el que se ha llamado «auge de la escuela de Madrid». De los momentos primeros es por ej. el proyecto de una colección de «comedias inéditas del teatro antiguo», la cual se llamará definitivamente «Teatro Antiguo Español» y tuvo su volumen inicial en el de Luis Vélez de Guevara, La serrana de la Vera, publicada por R. Menéndez Pidal y M. ${ }^{a}$ Goyri de Menéndez Pidal.

En la sección (que ya queda consignada) de «Orígenes de la lengua española» dirigida por Menéndez Pidal, se trabajó sobre una serie de documentos de Zamora que había obtenido — se nos dice- el Sr. Castro: efectivamente el 13 de octubre de 1911 Américo Castro leyó su Memoria para obtener el grado de doctor en Letras, y la publicó en 1913 con el título de Contribución al estudio del dialecto leonés de Zamora.

Asimismo se anunciaba la impresión de los Fueros leoneses (Zamora, Salamanca, Ledesma y Alba) cuyo texto habían preparado Federico de Onís y Américo Castro, y que en efecto acabarían por publicarse pronto (1916), aunque no apareció nunca el volumen proyectado con «una gramática y un vocabulario» de esos textos.

Don Américo - ciertamente - fue de manera administrativa oficial catedrático de Historia de la Lengua Española, pero en verdad sus intereses iban por otra parte, por los de una Historia de la cultura española primero del Renacimiento, y luego de las creencias religiosas en el suelo peninsular (en realidad al estudiar el Renacimiento se ocupaba ya de la creencia erasmista); no extraña así que su labor en torno a la diacronía lingüística resultase muy limitada, pues otros eran los afanes que llevaba en el alma. Se sintió perseguido en una España tradicionalmente católica por cuanto pertenecía a la minoría laica y republicana, y enlazó así de manera natural con los erasmistas y —en su tiempocon los krausistas: la lingüística debía resultarle un tanto abstracta y vacía si no aburrida, y dedicó por ello el afán investigador a problemas de historia de la cultura. Si en la actitud liberal y laica entroncaba con Menéndez Pidal, sus preocupaciones intelectuales le llevaban a Menéndez Pelayo: dicho simplificadamente y para entendernos, él era un Menéndez Pelayo de izquierdas, mientras su maestro don Ramón enlazaba naturalmente a su vez con el Menéndez Pelayo historiador de la literatura y exaltador del Quinientos español. De esta forma los previstos Gramática y vocabulario de los Fueros leoneses quedaron sin hacer.

El joven Américo Castro de hacia sus cuarenta años era según decimos un catedrático de materias lingüísticas, pero interesado por la historia espiritual de España; hizo así en los años del «Centro» obras como El pensamiento de Cervantes (1925), o el volumen Santa Teresa y otros ensayos (1929). Hasta obtener la cátedra, el joven Américo preparó algunos artículos y notas de materia idiomática, pero al conseguirla se ocupó prioritariamente de lo literario, y el mejor logro fue el libro sobre Cervantes, en el que se ocupaba de las doctrinas literarias del autor, de sus ideas sobre la Naturaleza y sobre lo religioso, etc. A su vez Santa Teresa y otros ensayos agrupaba un conjunto de escritos de asunto medieval o de los siglos XVI y XVII. 
La Memoria de la JAE correspondiente a 1914 y 1915 registra novedades de organización de relieve —que quedan anticipadas- en el «Centro de Estudios Históricos». Menéndez Pidal figura ahora como presidente del mismo, y además en tanto director de la «Sección de Filología»: sin duda las labores emprendidas desbordaban ya las fronteras del solo análisis de los orígenes de la lengua, y de ahí el nuevo rótulo de «Sección de Filología». Tras los naturales tanteos de los comienzos y una vez consolidada la Junta como institución, la escuela específicamente filológica (y comprehendedora de todo lo filológico) pidalina, entraba ya en su mayor plenitud, plenitud que fructificaría en obras notables y en la inmensa obra personal de don Ramón.

Un trabajo colectivo del que ahora se nos da noticia en cuanto se hallaba ya en marcha, es el de un Glosario general de la Edad Media. El logro de vida y trabajo de los colaboradores del Centro les daba fuerzas para todo, y así se nos da esta información: «Desde comienzos de 1915 vienen recogiéndose en el Centro de estudios históricos — bajo la dirección del Sr. Castro- materiales para un Diccionario de la lengua castellana hasta fines del siglo XV. La necesidad de tal trabajo era manifiesta, y ha parecido de [...] posible realización [...] dada la cantidad de textos, relativamente pequeña, que constituye la literatura medioeval [...] . Desde ahora, los materiales que se están acumulando prestan un notable servicio para muchos de los trabajos que el Centro tiene emprendidos. Hasta la fecha cuenta el glosario con un caudal de 90.000 papeletas, en su mayoría de obras medioevales».

Además de su finalidad última de llegar hasta un Glosario general medieval, el trabajo que se estaba haciendo servía para ilustrar y facilitar otras labores que se hallaban en curso.

Luego y desde finales de 1930, se forma el «Archivo de la Palabra» con el propósito de recoger y conservar en discos de gramófono: «a) La lengua española [...] en su uso corriente y en sus manifestaciones artísticas; $b$ ) Idiomas y dialectos hablados en la Península y en los demás países hispánicos [...]; c) Testimonios autofónicos de personalidades ilustres; $d$ ) Canciones, melodías y ritmos populares y tradicionales».

La Sección de «Literatura Contemporánea» —nos da cuenta la Memoria de 1932_ quedó creada en Marzo de ese año, y ya en Junio empezó a hacer la publicación de «Archivos de Literatura Contemporánea. Indice Literario». El número inicial de «Indice» efectivamente — podemos comprobarlo directamente—, se abre con un comentario más amplio de los «Ensayos sobre el sentido de la cultura española» de Federico de Onís, y siguen luego reseñas de libros publicados de a Abril a Junio de tal año en curso; el comentario general del número segundo se halla dedicado a «La novela de lo actual»; en el quinto se comenta el libro de Marañón sobre Amiel; etc.

En Septiembre de 1933 —nos informa ahora la Memoria de 1933 y 1934 - se constituyó en el Centro una nueva Sección de Estudios Hispanoamericanos bajo la dirección de Américo Castro, en la que colaboraban Ramón Iglesia o Ángel Rosenblat; aunque aquí no se nos diga por no tratarse de una publicación de la Junta, el grupo hispanoamericanista —en parte- colaboró en la nueva revista trimestral que empezó entonces Tierra Firme; en la entrega inicial figura como director de la misma Enrique DíezCanedo, y Montesinos está de redactor-jefe.

El desaparecido prof. Juan Manuel Rozas supo concretar algo por lo demás bien visible: que los hombres del «Centro de Estudios Históricos» no se dedicaron en general a 
los siglos XVI y XVII sino a lo lingüístico y a lo medieval. Estos hombres del «Centro» — escribía en bello párrafo transcrito de un dictado oral suyo — no fueron grandes especialistas en el Siglo de Oro «sino más bien medievalistas, historiadores, fonetistas, gramáticos, dialectólogos, basta la labor de Menéndez Pidal y la de [Erasmo] Buceta, [Américo] Castro, etc., para ver una labor en torno a los clásicos de primer orden. [...] En general se defendió [en el "Centro"] lo que de conflictivo, con palabra de hoy, tenían muchos escritores. Se defendió a los Valdés en cuanto heterodoxos y a Cervantes en cuanto erasmista, etc. [...] Remansaron y detallaron el Siglo de Oro en ciertos aspectos demasiado rotundos en manos de don Marcelino».

Desde el horizonte de la investigación literaria, publicaciones notorias que se hicieron en los años del «Centro de Estudios Históricos» fueron por ej. las obras ya mencionadas o que vamos a mencionar Antología de prosistas españoles (1932) y Poesía juglaresca y juglares de don Ramón; El pensamiento de Cervantes de Américo Castro; La lengua poética de Góngora de Dámaso Alonso; los estudios sobre los Valdés de José Fernández Montesinos; la monografía sobre Garcilaso de la puertorriqueña Margot Arce; etc.

\section{Amado Alonso}

En la generación intelectual española de 1914 hicieron estudios o ensayos de materia literaria, dentro o fuera del «Centro» $-\mathrm{y}$ los mencionamos sin orden especial alguno- - Ortega y Gasset, Miguel Romera Navarro, Fernando Vela, Salvador de Madariaga, Rafael Cansinos Asséns, Tomás Navarro Tomás, Américo Castro, Federico de Onís, Enrique Díez Canedo, el historiador Rafael Altamira, Julio Casares, Homero Serís, Miguel Artigas, Eduardo Martínez Torner, Federico Ruiz Morcuende, ... Desde el punto de vista teórico-conceptual sobre todo Ortega, Américo Castro o Fernando Vela, etc., reclaman nuestro interés. Pero las teorizaciones más activamente operantes en la ciencia filológica han sido las de dos miembros de la posterior generación del 27: aludimos a los dos Alonso (Amado y Dámaso), a quienes vamos a considerar ahora.

La «escuela de Madrid» de la que estamos dando noticia alcanzó lo que se ha llamado una proyección hacia América: Solalinde y Onís fueron a Universidades de los Estados Unidos, y en la dirección del «Instituto de Filología» de la Universidad de Buenos Aires pasó Amado Alonso una etapa institucional y personalmente decisiva (19271946), si bien en contacto siempre con los maestros y la labor que simultáneamente se hacía en el «Centro» madrileño.

Diego Catalán ha expresado gráficamente el papel desempeñado por el inicialmente joven de unos treinta años Amado Alonso en su estancia argentina: «A. Alonso, serio y versátil a la vez, dotado de una sólida formación en fonética experimental, en gramática histórica y en dialectología y al mismo tiempo extremadamente alerta para todo movimiento vanguardista (gramatical o lingüístico, filológico o literario), fue en Buenos Aires "the right man un the right place"» (Catalán, D, 1974:100-101).

A Amado no le pasó inadvertido en concreto el nuevo rumbo que adquirió la prosa española en el primer tercio — digamos— del siglo XX. Él expuso oralmente nada más llegar a Buenos Aires y referirse a Valle, y luego por escrito en la fecha temprana de 1935 y cuando aún casi se carecía de perspectiva temporal, cómo «desde nuestro clasicismo ["Herrera, 
fray Luis, Quevedo, Santa Teresa, etc."] hasta la llamada generación del 98 la lengua literaria fue declinando» por el acatamiento semiidolátrico de los escritores a las formas clásicas; sin embargo «ahora en cada página —escribía— es inconfundible el timbre de voz de Unamuno, de Azorín, de Valle-Inclán, de Juan Ramón, de Ortega y Gasset, de Pérez de Ayala, de Gabriel Miró. Y nuestra lengua ha multiplicado su potencia expresiva en todos los modos del espíritu: para las sensaciones y para los sentimientos, para la fantasía y para el pensamiento especulativo, $\mathrm{y}$ hasta para los modos de la voluntad». A otros filólogos tampoco les ha pasado inadvertido desde luego el relieve de la prosa artística de nuestro Novecientos, pero es asunto que aún no ha encontrado a un investigador sistemático.

El joven Amado había adquirido la mejor formación en cuanto fonetista, y así al llegar al Instituto de Filología de la Universidad de Buenos Aires redactó enseguida un escrito que denominó «Reconciliación con la Fonética», y que importa por su fondo doctrinal vossleriano e idealista (para el inventario de los textos de don Amado cfr. Palomo, B., 2004). El Amado Alonso que escribe en los mismos años del «Centro» y en conexión con él aunque fuera de él, sienta en varios trabajos de apariencia sólo lingüística sus criterios y postulados de doctrina, y por eso vamos a repasar tales trabajos (que por lo demás resultan muy poco conocidos).

La fonética podría parecer — argumentaba— «la manifestación más hedionda del difunto positivismo», pero esto sólo ocurre si se toma en sí y por ella misma; si la tomamos como subespecialidad de la lingüística, posee en cambio interés. De esta manera puede enunciarse que «es imposible descuidar, sin daño grave, el conocimiento de la palabra misma en su acústica, ya que el sonido es al significado no lo que el vestido al cuerpo, sino lo que el cuerpo al alma»; se trata pues de que sonido y significación resultan inseparables, y de que el sonido — se diría que viene a insinuársenos, aunque el autor no se lo propusiera - resulta pertinente para el significado.

La fonética no vale por sí misma, pero sí considerada — dice Amado-idealísticamente, o sea, en cuanto en los cambios diacrónicos resulta expresión o manifestación del espíritu libre del hombre: «todo lo que en fonética - formula — no sea apuntar por elevación a esos blancos idealistas, no será más que fisiología y acústica». De manera terminante nuestro autor proclama que «el objeto de la lingüística es conocer las relaciones causales entre nuestro espíritu y los actos de expresión»: podemos decir que en mostrar y razonar tales relaciones de causalidad consiste el idealismo proclamado por Vossler, y que Amado Alonso postula el buen positivismo del conocimiento adecuado de lo fonético no para quedarse en ello, sino para explicarlo a la luz de las motivaciones libres y espirituales del hablante. Esencialmente esto es —nos parece— lo que viene a decir el joven Amado, que además glosa entonces hacia el final de su trabajo el Manual de pronunciación de su maestro don Tomás Navarro.

Otro escrito alonsino se rotula «Lingüística espiritualista». En las presentes páginas proclama decididamente nuestro autor, y frente a la lingüística entendida en tanto estudio naturalista del idioma: «Esta concepción del lenguaje ha sido ya superada». Y explica así, de manera muy pedagógica: «El lenguaje como expresión es un acto espiritual, y nadie puede señalar leyes a los movimientos del espíritu. Podremos consignarlos después de cumplidos, pero nada más. Si vemos que en un grandísimo número de palabras españolas $c l$ se ha convertido en $j$, no lo interpretemos como ley que pesó sobre el español, sino como acto espiritual, es decir, libre, de un antepasado nuestro que creó tal expresión de 
modo determinado [...]; lo demás queda a cargo de la tendencia a la nivelación, innegable en la colectividad.Total, dos razones espirituales: creación y nivelación».

En efecto la lengua — viene a decírsenos — es el reino de la libertad y de la sociabilidad, procesos ambos humanos y por tanto libres y no naturalistas y fatales. Las llamadas «leyes» lingüísticas no suponen sino la comprobación retrospectiva de un hecho originado en la individualidad del ser humano y en su sociabilidad.

Amado concluía su pasaje manifestando que tanto las creaciones lingüísticas como las consecuentes nivelaciones revelan el estilo del pueblo que habla el idioma de que se trate: en la diacronía se van manifestando ciertamente los gustos idiomáticos o estilos del hablar, los cuales en conjunto darán lugar a la identidad un idioma. El joven Amado está teorizando en realidad acerca de lo que su maestro Menéndez Pidal acababa de mostrar en su libro Orígenes del español aparecido unos meses antes (y acaso incitado por tal texto), y sienta por lo demás una visión de la diacronía que es la que impregnará años más tarde el libro señero de Eugenio Coseriu Sincronía, diacronía e historia.

La proclama de Amado Alonso se repite otra vez en sus páginas: «La lingüística — manifiesta— cambia de orientación. Se estudia cada forma como expresión, como función ['dependencia'] espiritual. Estas formas no son ya hechos, sino actos; no estados, sino fenómenos», de tal manera que el hombre crea la forma expresiva en la libertad de su espíritu. La capacidad expresiva, la no ineluctabilidad (= la libertad) en el modo concreto de expresarse, la adaptación a la sociabilidad, es lo que subyace a las formas idiomáticas que se usan en una comunidad hablante, y no ninguna supuesta legalidad ciega e inexorable. Así reza la tesis que él mismo denomina «espiritualista» de Amado Alonso, y tal como decimos según ella habían sido concebidos en buena medida los Orígenes del español pidalinos; el joven Amado escribe ahora de manera muy diáfana sobre esta teoría del lenguaje que preside una parte de la obra del «Centro de Estudios Históricos», es decir, de lo que se ha denominado la «escuela de Madrid».

No obstante, este espiritualismo en lingüística y en filología ha de resultar técnicamente muy riguroso, ha de estar científicamente fundamentado y comprobado, por lo que el autor navarro manifiesta también sus reservas frente a la obra de Vossler, quien se lanza a construir — manifiesta— «sin la prudente comprobación de materiales, con una alegre falta de responsabilidad», y así edifica «castillos en el aire». Hubo ciertamente hacia fines de estos años veinte (del siglo XX) una insatisfacción ante las elaboraciones particulares de Karl Vossler: se reconocía su labor programática, pero se disentía de esas elaboraciones particulares. De hecho a la vez del artículo del joven Amado, fue Gerhard Rohlfs quien por su lado publicaba la conferencia Lengua y cultura, en la que asimismo estimó que los resultados ofrecidos por los idealistas «de momento sólo pueden aceptarse con mucha reserva».

En fin el autor navarro definía de esta manera: «Yo llamaría Lingüística a la ciencia espiritualista que estudia los actos del lenguaje como creaciones del espíritu individual, como intuiciones exteriorizadas en sonidos. Y llamaría Filología a la ciencia espiritualista que estudia los problemas del lenguaje relacionados más bien con el triunfo y caducidad de esas creaciones individuales en la colectividad, estudio mucho más circunstanciado —época, geografía, clase social, etc.—y más histórico que filosófico».

Las ciencias del lenguaje son siempre así espiritualistas, es decir, humanísticas, no naturalistas, y se deben ocupar a veces de la creación expresiva idiomática de carácter in- 
dividual, y en otras ocasiones de la realidad histórica de las formas o creaciones idiomáticas, realidad que es tanto cronológica como espacial y también diastrática y diafásica. Justamente la obra ya mencionada Orígenes del español — denominada aquí por nuestro autor «maravilloso libro»-, lo que hizo fue falsar el positivismo naturalista de los estrictos neogramáticos mediante el manejo de los datos geográficos y cronológicos.

Un discurso leído por Amado fue el que tituló «Valor histórico de la lingüística», en el que enuncia primero el concepto de latín vulgar, opera con el concepto de «nivelación idiomática», etc., y postula que «las pronunciaciones fillo, ollo, orella, debieron existir en Castilla ya en la época de las invasiones bárbaras. Es muy verosímil que se oyera ya [la prepalatal fricativa sonora] entre las clases menos cultas [...]. En esos tres siglos (V-VIII) tiene lugar la mayor parte de los cambios lingüísticos en los idiomas latinos». El autor sugiere por tanto que en la época visigótica el habla diaria más familiar debía obedecer ya a una fonética romance, idea que reproduce — con algún matiz—otra más o menos análoga de Menéndez Pidal expuesta en Orígenes... y que los latinistas no aceptan.

Amado declaró — según la versión escrita sintetizada que poseemos de su conferencia - que deseaba exponer «cómo se entroncan los estudios lingǘsticos dentro de la historia», y enunciaba así en tanto principio general de las ciencias humanas que cada serie de hechos «quedará ininteligible [...] hasta que no la asociemos a todas las otras series con las que está ligada. El descubrimiento del nexo que las une nos pone inmediatamente en posesión de su razón de ser». La historia idiomática —vale decir—, la política, la literaria, se hallan implicadas o enlazadas en parte unitariamente, y tal unitariedad es la que acabará de explicárnoslas.

Otro de los primeros trabajos argentinos de don Amado fue el referido a la «Estructura de las Sonatas de Valle-Inclán», trabajo que se hace eco implícito de Vossler al decir que «el conjunto de las Sonatas tiene un excepcional interés literario en cuanto las miramos como un conjunto de problemas técnicos resueltos de un modo personal»: en efecto Vossler postuló que en la serie literaria más lograda no encontraremos sino problemas estéticos a los que se ha dado solución eminente.

El maestro navarro tiene en cuenta ahora la «doble esencia de significación» — tal como dice- que poseen los vocablos, su carga tanto intelectual como afectiva, y según este hecho analiza pasajes del texto de las «Sonatas» (por ej. la metáfora «ojos [...] guarnecidos de lágrimas»); asimismo detecta en la prosa de Valle-Inclán la bien conocida combinación de tres adjetivos seguidos de una comparación. Etc.

Amado Alonso escribió también — ya en 1932 — un «Propósito» al frente de su «Colección de Estudios Estilísticos», y expuso cómo Bally había sistematizado los «humores subjetivos» que lleva en sí la palabra —emociones, valoraciones, fantasías, voliciones- además de su poder comunicativo, y cómo a la nueva disciplina la denominó Estilística; y si la Estilística — completaba — en cuanto investigación de lo afectivo en la lengua corriente ha alcanzado estatuto y responsabilidad científicos, la «Ciencia de los estilos, como investigación del acento personal en la lengua literaria de un autor, también $1[\mathrm{os}]$ tiene».

Debemos quedarnos con esta proposición de una «Ciencia de los estilos» literarios que se ha de ocupar del acento personal de cada autor; no obstante, hacia el final de su vida don Amado precisó las cosas en un párrafo que por su importancia debemos copiar y considerar: «La significación tiene siempre carácter lógico, pero en el contenido de una 
expresión hay siempre otras sustancias que no pertenecen a la esfera de lo lógico. Se emplea generalmente el nombre de estilística para el estudio de esas sustancias extra-intelectuales. [...] La estilística del habla se ocupa de los estilos individuales, prácticamente de los literarios; la estilística de la lengua se ocupa de las sustancias afectivas, imaginativas, activas y asociativas que integran con la referencia lógica [...] el contenido total de una expresión [...] como contenido comúnmente compartido y vivido por todos los que hablan la lengua correspondiente».

El contenido de las expresiones idiomáticas no es sólo lógico sino que está integrado por sustancias emotivas, de la fantasía, actuativas, o valorativas (hierbajo, vejete), y tales sustancias en cuanto pertenecen a la lengua común las analiza la estilística de la lengua o estilística propiamente dicha; la ciencia de los estilos literarios o estilística del habla se ha de ocupar de la expresividad individual, de los estilos literarios particulares. A su vez Menéndez Pidal pensaba que el de los principales estilos literarios es uno de los capítulos de cualquier Historia de una lengua dada.

Hacia el final de los años del «Centro» — final determinado por la guerra civil— don Amado envió para publicarse en Madrid un artículo que rotuló «Vida y creación en la lírica de Lope», y en el mismo estampaba este principio metodológico: «Tan ruinoso nos resulta prescindir de la vida del poeta como tomarla ingenuamente por el contenido poético de la obra». Se trata en efecto de saber si la obra artística resulta por completo una forma inmanente o si lleva en ella referencias de lo real, y la postura del maestro navarro resulta sensata y adecuada: el crítico habrá de contar con los datos biográficos en cuanto resulten pertinentes, pero en ningún caso podrá identificar la vida real (que es extraliteraria) con el texto literario tal como se nos da. En Lope desde luego, pero asimismo García Lorca, también en lo que se refiere a algunos aspectos de Galdós, etc., habrá de prestarse atención a lo biográfico.

Insistiendo en que no cabe identificar sin más y en correlación absoluta la realidad y la literatura, Amado Alonso enuncia en estas mismas páginas que lo poético consiste en una estructura, una construcción en la que «los elementos estructurales son el sentido emocional de las cosas y no las cosas mismas».

En 1940 dio a luz don Amado su verdaderamente lograda monografía Poesía y estilo de Pablo Neruda, muy analítica y que no deja de incluir pasajes teóricos; es obra que debe leerse indispensablemente.

De 1941 es el manifiesto teórico «Carta a Alfonso Reyes sobre la estilística», y en el mismo Amado Alonso sostiene en esencia que la estilística —entiéndase, la estilística literaria- atiende «a lo que de creación poética tiene la obra», es decir, a su especificidad literario-expresiva; es obligación de la ciencia de la literatura (proclama) intentar el conocimiento metódico de lo poético en la obra literaria, esto es, el conocimiento de la especificidad de ese texto, el de esa obra en sí (Alonso, A., 1965, 78-86).

La ciencia de los estilos literarios o estilística — concreta más Amado- estudia «el sistema expresivo de una obra o de un autor, o de un grupo pariente de autores, entendiendo por sistema expresivo desde la estructura de la obra [...] hasta el poder sugestivo de las palabras»; todo lo que es artificio, todo lo artístico, deberá quedar incluido en la estilística, que analiza por tanto sistemas expresivos.

En el artificio expresivo de la obra hay que considerar por igual los pensamientos e ideas de la misma considerándolos en tanto «una visión intuicional del mundo que se 
cristaliza precisamente en esta obra estudiada», es decir, que han de tenerse presentes las ideas que es posible descubrir en una obra en cuanto se encuentran expresadas artísticamente, e. gr., la defensa del orden señorial y monárquico no como puede aparecer en un tratado político, sino en cuanto aparece en una comedia de Lope. Al estudioso de la literatura no le importa la sustancia de contenido por sí misma, las ideas, sino las ideas unidas inseparablemente a su manifestación y expresión en la obra. De esta manera la estilística ha de saber que en la obra de arte no todo se acaba en lo que nuestro autor denomina su delicia estética - la emoción estética, diríamos nosotros-, sino que ocurre que «hay valores culturales, sociales, ideológicos, morales [...] que esa ciencia de los estilos no puede ni quiere desatender».

Amado Alonso podemos interpretar que reclama el análisis literario de la obra en sí y a la vez de lo que en la obra no es en sí (las sustancias de contenido), aunque no perdiendo nunca de vista la consistencia del texto en sí.

$\mathrm{Al}$ año siguiente, en 1942, el maestro navarro publicaba un artículo complementario al que llamó «La interpretación estilística de los textos literarios»; en realidad es otra exposición de las mismas ideas de la «Carta...», y debió ser escrito simultáneamente. Queda no obstante fuera de la cronología del Centro de Estudios Históricos al igual que la «Carta», aunque hemos hecho referencia a ella porque hemos encontrado en la misma alguna idea que no suelen subrayarse.

Demos noticia asimismo de que Amado Alonso publicó en el mismo 1942 el volumen compuesto por dos monografías Ensayo sobre la novela histórica. El modernismo en «La gloria de don Ramiro».

En fin, cabe recordar cómo nuestro autor dedicó los años últimos de su corta vida (cincuenta y cinco años) al estudio de la historia de la pronunciación española, lo que dio lugar a dos tomos bien conocidos y a uno tercero que permanece inacabado e inédito.

Don Amado resultó pionero en los estudios estilísticos de la escuela de Madrid y en general de toda la filología española: cultivó lo mismo la estilística lingüística (el artículo, los diminutivos, los verbos de movimiento en español) que la literaria; él se propuso en el análisis de los estilos literarios «la cristalización de la informe "materia" psíquica en una “forma"» (Catalán, D., 1974: 104).

\section{DÁmAso AlONSO}

Si se considera a Menéndez Pidal más bien como lingüista, filólogo e historiador de la literatura, acaso el puesto más alto del siglo XX en cuanto a la crítica literaria específicamente - por su dedicación académica constante a la misma, además de por la calidad-, lo ocupa quizá Dámaso Alonso. Existe por fortuna una recopilación preciosa de sus trabajos, que es el conjunto de sus Obras Completas (Ed. Gredos), y en las mismas vamos viendo varios títulos señeros en particular: «Vida y obra de Medrano»; «Góngora y el «Polifemo»»; «La "Epístola moral a Fabio", de Andrés Fernández de Andrada»; etc. Todas estas aportaciones resultan de lectura necesaria, y asimismo nada puede suplir la lectura directa de su principal aportación teórica expresa, la del libro «Poesía española. Ensayo de métodos y límites estilísticos», posterior a la estancia del autor en el «Centro». 
Pero en los años de su colaboración en las empresas pidalinas, un entonces joven Dámaso Alonso hizo por ejemplo el escrito «Claridad y belleza de las "Soledades"» (1927), en el que inserta un párrafo que tiene mucho de teórico y que se halla referido al Barroco, que es un párrafo - además, y como se verá— muy de época, a saber: «Así como en el barroco las superficies libres [arquitectónicas] del clasicismo renacentista se cubren de decoración, de flores, de hojas, de frutos, de las más variadas formas arrancadas directamente a la naturaleza o tomadas de la tradición arquitectónica de la antigüedad, así también en las Soledades la estructura renacentista del verso italiano se sobrecarga de elementos visuales y auditivos, de múltiples formas naturales y de supervivencias de la literatura clásica que no tiene ya un valor lógico — no un simple valor lógico—, sino un valor estético decorativo. [...] Es éste [el no tener interés novelesco] uno de los mayores aciertos de Góngora y uno de los que más le aproximan al gusto de nuestros días: baste pensar en el desmoronamiento actual de la novela, o en otro orden, en los nuevos caminos, - puro placer de las formas - que han abierto a la pintura el cubismo y sus derivaciones. A menor interés novelesco, mayor ámbito para los puros goces de belleza» (Alonso, D., 1978, 293-317).

El joven Dámaso se encuentra instalado en la Vanguardia, y así se siente llevado a entender la estética del Barroco y la estética barroca de Góngora, y a proclamar un puro goce de la belleza; años más adelante, y al igual que su amigo Jorge Guillén, pasaría también de un «cántico» a un «clamor» por la injusticia del mundo.

El ya mencionado Rozas aludía agudamente a cómo el Veintisiete - y en él Dámaso Alonso- amplió el concepto que hasta entonces se tenía de nuestro «Siglo de Oro» mediante el rescate de valores como Góngora y el gongorismo, la lírica tradicional, ciertas zonas de Lope, el auto sacramental, ... «La ampliación que se iniciaba de la lírica barroca - fueron sus palabras - era a la vez estética, histórica e incluso metodológica, pues a través del estudio estilístico de Góngora se introducen en España formas de crítica muy novedosas, desde el idealismo de Croce o de Vossler»; así fue, y según todo el mundo sabe la labor de Dámaso Alonso resultaría a la vez histórica y teórica.

En los años del «Centro» nuestro autor compuso asimismo y editó más tarde su trabajo sobre «La lengua poética de Góngora», que es una de las obras más representativas de la investigación que llevó a cabo la escuela pidalina. En la misma propuso una interpretación global del poeta, la que dice que existen dos Góngoras, pero no cronológicamente sucesivos, sino coexistentes según una división longitudinal y no transversal de su obra: «a un lado las producciones en las que todo es belleza en el mundo, todo virtud, riqueza y esplendor; al otro las gracias más chocarreras, las burlas menos piadosas y la fustigación más inexorable de todas las miserias de la vida» (Alonso, D., 1978: 22).

Aunque luego la crítica ha insistido en que además hay dos Góngoras cronológicamente sucesivos (lo apuntan E. Orozco, F. Lázaro, etc., y con ellos coincidimos), el juvenil Dámaso dejó sentada esta tesis de la división longitudinal de toda su obra del principio al fin (de 1580 a 1626), en la cual por tanto alternan lo que él llamó un «plano escéptico» y un «plano entusiasta», que constituyen otras tantas manifestaciones del arte de don Luis.

El texto de La lengua poética de Góngora trata en sucesivos capítulos del cultismo tanto léxico como sintáctico, de las fórmulas estilísticas empleadas por el poeta —aunque cabe distinguir en el análisis más de las establecidas por nuestro crítico-, y del hipér- 
baton. Un tomo segundo del estudio iba a versar sobre la metáfora, la hipérbole, las alusiones, el ritmo y el color, etc., en el arte de Góngora; quedó sin publicar como tal, pero en cierto modo podemos decir que su contenido se halla presente en el otro trabajo de don Dámaso sobre «Góngora y el "Polifemo"». Ya queda dicho que «Poesía española» es obra cuya lectura personal no puede sustituirse — como no deben dejar de leerse los otros títulos mencionados-, y que es texto posterior a la guerra civil y al Centro de Estudios Históricos. Recogeremos sin embargo cómo en el ensayo que lleva a cabo de metodología estilística don Dámaso postula en lo fundamental un saber acerca de la peculiaridad del fenómeno artístico que constituye a cada obra, un saber o conocer acerca de su unicidad, de su ley particular interna, de lo que «le constituye y le constituye único» (Alonso, D. 1989: 7-522)

La Estilística - define a su vez- es la ciencia del estilo, del habla literaria, y el estilo es «lo peculiar, lo diferencial»; la Estilística o ciencia de la literatura se ocupa por tanto de algo caracterizador y diferencial como es cada habla literaria, cada estilo; por tal análisis de los estilos ha de avanzar la posible ciencia de la literatura.

Especifica además don Dámaso cómo el verdadero objeto de la estilística sería «la investigación pormenorizada de las relaciones mutuas entre todos los elementos significantes y todos los elementos significados» del texto. Se trata así de analizar «la estructura íntima del densísimo tejido poético», y de estudiar la obra de que se trate en cuanto «signo o forma literaria», en cuanto globalidad o unicidad diferenciada.

El «estilo» —abunda Dámaso Alonso- es la única realidad literaria; en lo literario (proclama así) «no hay más realidad fenoménica que el "estilo", o sea, el "signo" en su unicidad». Este signo constituido por el texto u obra de que se trate es el objeto —en la unicidad estética que presenta - de la ciencia literaria. El signo artístico posee asimismo contenido, y nuestro autor, se diría que siguiendo a Amado Alonso, manifestaba que el pensamiento o contenido, en cuanto expresado, pertenece también al estilo.

Hacia el final de su obra, don Dámaso enuncia «que el objeto de la Estilística es la totalidad de los elementos significativos del lenguaje (conceptuales, afectivos, imaginativos)», y «que el habla literaria y la corriente son sólo grados de una misma cosa». El estilo se halla por tanto lo mismo en lo imaginativo o afectivo de la obra que en su más neutra connotación conceptual, y así ha de tenerse presente en el análisis.

Don Dámaso es un autor decisivo en la historia de la teoría, la crítica y la historiografía literarias, y todos los volúmenes segundo a noveno de sus Obras Completas han de ser tenidos en cuenta obligadamente; los ocasionales pasajes en que se deja ir y hace literatura sobre literatura no pueden ocultar el alto rigor filológico que preside su obra y le da tono general.

Los casos de don Ramón Menéndez Pidal, y de Amado y Dámaso Alonso parecen sugerir que los mejores estudios literarios suelen lograrlos quienes además saben lingüística.

\section{APÉNDICE}

Las páginas anteriores quedaron redactadas hace unos cinco años, aunque luego hemos podido hacer algunas pequeñas adiciones en las mismas y hemos adelantado en al- 
gunas publicaciones varios párrafos. Se publican ahora en ocasión de los cuarenta años en este 2008 de la muerte de Menéndez Pidal, del centenario del nacimiento de Rafael Lapesa, y -tristemente- del fallecimiento de Diego Catalán en los meses últimos; además hemos publicado el libro Aproximación a la obra lingüística de Menéndez Pidal, y en Febrero organizamos una exposición en torno a la obra de Lapesa en el vestíbulo de la Biblioteca Central de la UNED. A propósito del prof. Catalán último discípulo de su abuelo don Ramón-, añadimos ahora la siguiente noticia.

El 9 de Abril de 2008 ha muerto Diego Catalán, alumno directo de Menéndez Pidal y de Lapesa, y — según diremos enseguida — probablemente el último filólogo estricto con el que podamos contar.

D. Catalán se doctoró muy joven en mayo de 1951 con la tesis «Crónica de Allfonso XI. Una redacción amplia desconocida», trabajo que se encuentra al inicio de una gran labor investigadora dedicada a este asunto. El autor ha relatado cómo «descubr[ió] la existencia en la Biblioteca Nacional de Madrid, de una versión inédita y desconocida de la historia de Alfonso XI mucho más "completa" que la Crónica por todos manejada: la bauticé [...] con el nombre de Gran Crónica de Alfonso XI», y cómo se sintió fascinado «por el interés histórico, historiográfico y literario del nuevo "clásico" medieval que tenía entre las manos»; el ponente de la tesis fue Rafael Lapesa.

Catedrático en La Laguna, permaneció largos años también en Universidades norteamericanas y europeas con las que colaboró (Wisconsin, Bonn, San Diego - hasta 1987/1988 — ,...); ha sido catedrático en la UAM, en la que ha llevado a cabo una relevante labor de dirección de estudios historiográficos en torno al rey Alfonso X y al primer cuarto del siglo XIV de manera particular.

Ha sido también director del «Instituto Interfacultativo "Seminario Menéndez Pidal"» y responsable asimismo como director en la parte última de su vida, de la Fundación Ramón Menéndez Pidal.

Los grandes temas de la investigación del prof. Catalán han resultado la historiografía, la lingüística histórica y dialectal, y el romancero; por fortuna buena parte de los escritos dispersos de una u otra temática se encuentran organizados en volumen. La densidad y originalidad de datos e interpretaciones de estos volúmenes y de los trabajos que quedan sin agrupar son tales, que cabe calificarlos con toda objetividad y justicia histórica de magistrales: pocas obras de investigación filológica han sido cumplidas en la España de la segunda mitad del siglo XX e inicios del siglo XXI como la de este autor. Diego Catalán, último miembro vivo hasta su muerte de la escuela directa pidalina, será acaso asimismo el último gran filólogo español y de la lengua española: la filología española en sentido propio y estricto (acaso de ahora en adelante ya imposible como tal filología debido a la creciente especialización del saber), abarcadora de la lengua, la literatura y la historia, va en nuestra cultura de Ramón Menéndez Pidal a Diego Catalán en los ciento diez años que transcurren entre 1896 y 2005 — por simbolizarlo en dos obras de tales fechas-.

Nuestro autor se inició según queda dicho con el estudio de la denominada por él Gran Crónica de Alfonso XI; de sus análisis primeros resultaron dos estudios en forma de libro, Poema de Alfonso XI. Fuentes, dialecto, estilo, Madrid, Gredos, 1953, más Un cronista anónimo del siglo XIV (La Gran Crónica de Alfonso XI. Hallazgo, estilo, reconstrucción), Universidad de La Laguna, 1955. 
Verosímilmente al Diego Catalán opositor a cátedras se debe el volumen La escuela lingüística española y su concepción del lenguaje, Madrid, Gredos, 1955: acaso es parte de su «Memoria» sobre el «concepto» $\mathrm{y}$ «método» de la asignatura.

Por los mismos años - la segunda mitad de los cincuenta-Catalán hizo varios escritos sobre fonética histórica y fonética dialectal: además de dedicarse al asturiano, nuestro autor - al igual que por entonces hicieron otros miembros de la escuela pidalina: el propio don Ramón, Lapesa, Galmés- prestó su atención al paso de la pronunciación medieval a la moderna en castellano, y a la constitución del llamado por él «español atlántico». Las páginas que datan de entonces y que se deben a los presentes cuatro estudiosos poseen — pasado prácticamente medio siglo— absoluta vigencia científica. De D. Catalán en concreto deben verse sus dos recopilaciones — que incluyen por igual escritos anteriores o posteriores-El español. Orígenes de su diversidad, Madrid, Paraninfo, 1989, y Las lenguas circunvecinas del castellano. Cuestiones de dialectología hispano-románica, Madrid, Paraninfo, 1989. A final de los años sesenta nuestro autor había redactado asimismo - por encargo de una especie de enciclopedia internacional de conjunto- las páginas que en volumen exento constituyeron el libro Lingüística Íbero-románica. Crítica retrospectiva, Madrid, Gredos, 1974; un Catalán muy maduro pasa revista a lo que él entiende que se ha hecho en nuestras disciplinas, y de esta manera «trata de ofrecer una visión detallada de lo realizado en "cien años de lingüística hispano-románica", tomando como fecha terminal la década de los 60». El trabajo resulta de lectura instructiva, y en la presentación del mismo se encuentra el presente alegato acerca de cómo entre nosotros no suele hacerse sana crítica intelectual, sino que al compañero de oficio o se la da bombo, o se le anatematiza y excluye: «En nuestro medio cultural siempre inclinado al aprovincianamiento, la crítica crítica es desusada (al colega o se le bombea o se le empluma; pero más bien por razones de índole personal que por divergencias en la apreciación de los hechos descritos o por disentimientos teóricos)»; ya el joven Ortega y Gasset advirtió con palabras estremecedoras cómo «merced a causas desconocidas, la morada íntima de los españoles fue tomada tiempo hace por el odio». D. Catalán volvería a sus preocupaciones de la época en que fue catedrático en La Laguna con el discurso Tomando tierra en la «Romania Nova» (2006).

Pero aunque nuestro autor cultivase la lingüística en sus dos aspectos diacrónico y dialectal, la impronta del ejemplo y las enseñanzas de su abuelo don Ramón se hace patente acaso en su mayor dedicación — quizá por este orden de interés— a la historiografía, al romancero, y a la épica.

La dedicación al romancero desde muy joven y hasta años avanzados de su vida ha cuajado en una amplia labor de dirección de encuestras y de editor, y en particular en sucesivos volúmenes de rigurosos estudios propios: Siete siglos de romancero. Historia y poesía, Madrid, Gredos, 1969; Por campos del romancero. Estudios sobre la tradición oral moderna, Madrid, Gredos, 1970; Arte poética del romancero oral. Parte 1. ${ }^{a}$. Los textos abiertos de creación colectiva, Madrid, Fundación Ramón Menéndez Pidal y Siglo Veintiuno, 1997; Arte poética del romancero oral. Parte 2. ${ }^{a}$. Memoria, invención, artificio, Madrid, Fundación Ramón Menéndez Pidal y Siglo Veintiuno, 1998; etc.

La obra cumplida en historiografía — de edición y de análisis y estudio de textos fundamentales - es muy amplia, y ha dado volúmenes como estos que enumeramos: De Alfonso X al Conde de Barcelos. Cuatro estudios sobre el nacimiento de la historiografía 
romance en Castilla y Portugal, Madrid, Gredos, 1962; Crónica de 1344 (edición crítica del texto español, en colaboración con Soledad de Andrés), Madrid, Gredos, 1970; La tradición manuscrita en la «Crónica de Alfonso XI», Madrid, Gredos, 1974; Crónica del moro Rasis (romanzada hacia 1300; edición pluritextual en colaboración con Soledad de Andrés), Madrid, Gredos, 1974; Gran Crónica de Alfonso XI (edición crítica), Madrid, Seminario Menéndez Pidal y Editorial Gredos, 1977, dos tomos; La Estoria de España de Alfonso X. Creación y evolución, Madrid, Fundación Ramón Menéndez Pidal y UAM, 1992; De la silva textual al taller historiográfico alfonsí. Códices, crónicas, versiones y cuadernos de trabajo, Madrid, Fundación Ramón Menéndez Pidal y UAM, 1997; «Rodericus» Romanzado en los reinos de Aragón, Castilla y Navarra, Madrid, Fundación Ramón Menéndez Pidal, 2005 (con la colaboración de Enrique Jerez).

Sin dejar de ocuparse de la historiografía y en conexión con ese estudio, Diego Catalán intensificó en los que habían de ser los años últimos de su vida el estudio del Mio Cid y de la épica castellana, lo que dio lugar a dos extensas obras, a saber: La épica española. Nueva documentación y nueva evaluación, Madrid, Fundación Ramón Menéndez Pidal, 2000, y El Cid en la historia y sus inventores, Madrid, Fundación Ramón Menéndez Pidal, 2002.

Si se lee con responsabilidad la obra entera de Diego Catalán, la justicia histórica obliga a decir que supone una de las contribuciones de mayor amplitud y solidez científica de las que se han hecho a los estudios filológicos españoles en la segunda mitad del siglo XX y a comienzos del siglo XXI. Según venimos manteniendo, por imposición de las nuevas circunstancias históricas los análisis propiamente filológicos puede decirse ya que han transcurrido entre la obra de Ramón Menéndez Pidal y la de Diego Catalán, entre las fechas simbólicas de 1896 y 2005.

\section{REFERENCIAS BIBLIOGRÁFICAS}

ABAD, Francisco, Introducción a la historia de las doctrinas literarias en España, Madrid, Editorial de la UNED, 2005 (segunda ed. aumentada).

ABAD, Francisco, Historia general de la lengua española, Valencia, Tirant lo Blanch, 2008.

Alonso, Amado, Materia y forma en poesía, Madrid, Gredos, $1965^{3}$.

Alonso, Dámaso, Obras Completas, Madrid, Gredos, V, 1978; IX, 1989 [estos volúmenes incorporan textos de fechas anteriores].

Bartolomé Cossío, Manuel, De su jornada, Madrid, Imprenta Blass, 1929.

Catalán, Diego, Lingüística Íbero-Románica, Madrid, Gredos, 1974.

MenÉndez Pidal, Ramón, Poesía juglaresca y juglares, Madrid, Centro de Estudios Históricos, 1924.

MENÉNDEZ PIDAL, Ramón, «El lenguaje del siglo XVI», en La lengua de Cristóbal Colón, Madrid, Espasa-Calpe, $1968^{5}$, pp. 47-84 [1933; citamos según la versión definitiva].

MENÉNDEZ PIDAL, Ramón, La lengua castellana en el siglo XVII, Madrid, Espasa Calpe, 1991 [c.1941].

MenÉndez Pidal, Ramón, Los españoles en la literatura, Madrid, Espasa-Calpe, $1971^{2}$ [1949].

MEnÉndez PidAl, Ramón, «La lengua en tiempo de los Reyes Católicos», Cuadernos Hispanoamericanos, 13, 1950, pp. 9-24.

MENÉNDEZ PIDAl, Ramón, Poesía juglaresca y orígenes de las literaturas románicas, Madrid, IEP, 1957a. 
MENÉndez PIDAL, Ramón, España y su historia, Madrid, Minotauro, 1957b, II.

MENÉNDEZ PIDAL, Ramón, «El lenguaje español en tiempo de Felipe II», en El Escorial. 1563-1963, Madrid, Patrimonio Nacional, 1963, I, pp. 531-562.

MENÉNDEZ PIDAL, Ramón, La «Chanson de Roland» y el neotradicionalismo, Madrid, Espasa-Calpe, 1959.

MENÉndez PIDAL, Ramón, Romancero Hispánico. Teoría e historia, Madrid, Espasa-Calpe, $1968^{2}$. MENÉNDEZ PidAl, Ramón, En torno al «Poema del Cid», Barcelona, Edhasa, 1970 [reimpresión]. MENÉNDEZ PIDAL, Ramón, Estudios sobre el romancero, Madrid, Espasa-Calpe, 1973.

MENÉNDEZ PIDAL, Ramón, Historia de la lengua española, Madrid, Fundación Ramón Menéndez Pidal-RAE, 2005.

Palomo, Bienvenido, Bibliografía de Amado Alonso, Cáceres, Universidad de Extremadura, 2004.

\section{OTRAS REFERENCIAS}

ABAD, Francisco, Diccionario de lingüística de la escuela española, Madrid, Gredos, 1986 (con bibliografía en las pp. 35-41; el autor tiene además en forma de artículo bastantes otras aportaciones).

ABAD, Francisco, Aproximación a la obra lingüística de Menéndez Pidal, Madrid, Dykinson, 2008.

Alonso, Dámaso, Obras Completas.IV. Ensayos sobre literatura contemporánea, Madrid, Gredos, 1975 (incluye artículos sobre Pidal, A. Castro, y Lapesa).

CATALÁn, Diego, Lingüística Íbero-románica. Crítica retrospectiva, Madrid, Gredos, 1974 (muy orientador).

CATALÁN, Diego, El archivo del romancero[,]patrimonio de la humanidad, Madid, Fundación Ramón Menéndez Pidal, MMI (aportación necesaria y preciosa).

García IsASTI, Prudencio, La España metafídica. Lectura crítica del pensamiento de Ramón Menéndez Pidal (1891-1936), Bilbao, Euskaltzaindia, 2004 (finas verdades y quizá también algún fino error).

LAPESA, Rafael, «Menéndez Pidal, creador de escuela: el Centro de Estudios Históricos», en el librito con otros autores iAlça la voz, pregonero!, Madrid, Cátedra-Seminario Menéndez Pidal, 1979, pp. 43-79.

LAPESA, Rafael, Generaciones y semblanzas de filólogos españoles, Madrid, Real Academia de la Historia, 1998 (artículos vivenciales y de testimonio).

NAVARro Tomás, Tomás, «Don Ramón Menéndez Pidal en el Centro de Estudios Históricos», en el Anuario de Letras, VII, 1968-1969, pp. 9-24.

Pérez Pascual, José Ignacio, Ramón Menéndez Pidal, Valladolid, Junta de Castilla y León, 1998 (con bibliografía en las pp. 383-398).

Pérez Villanueva, Joaquín, Ramón Menéndez Pidal. Su vida y su tiempo, Madrid, Espasa- Calpe, 1991.

PORTOLÉs, José, Medio siglo de filología española (1896-1952), Madrid, Cátedra, 1986 (visión a veces un tanto sombría de los logros de la escuela; no menciona a R. Lapesa).

Rodríguez Mediano, Fernando, Pidal[,] Gómez-Moreno[,]Asín. Humanismo y progreso, Madrid, Nivola, 2002.

Tovar, Antonio, «Sobre la escuela de Menéndez Pidal», en La Torre, 70-71, 19701971, pp. 75-93. 